\title{
Research on the Evaluation and Optimization of Governmental Tourism Official Website at County and City Levels Based on Hierarchical Analysis
}

\author{
Take Hainan as an Example
}

\author{
Fuyuan Bao \\ International Hospitality Management School \\ University of Sanya \\ Sanya, China 572022
}

\begin{abstract}
Set up the evaluation system and index weight of the secondary index which contain e-government, information service, website design, online transaction, interactive communication, customer relationship management, etc by analytic hierarchy process for tourism official website of county and municipal level and take Hainan as an example to evaluate. We find that the tourism official website of county and municipal level is in the middle and low level overall. The degree of education of tourism official website of county and municipal in south is high, followed by north and east and the west and the middle are weaker. In view of indicator, the level of information service and website design is higher, the level of interactive communication is general and the level of e-government, online transaction and customer relationship management is lower. narrowing the gap between city and county tourism official website information, improving online trading information and channels and optimizing website layout design and highlight interactive function are the suggestions from us.
\end{abstract}

Keywords-analytic hierarchy process; tourism official website; E-government; informatization

\section{INTRODUCTION}

As an international tourism island under the concept of global tourism, the construction level and difference of city and county government tourism official website in Hainan can affect the tourism image of islandwide. Take Hainan as an example, it is significant for enhancing the application value and informatization level of tourism official website to study the effect and difference of the informatization application of tourism websites in various cities and counties.

\section{RESEARCH STATUS AT HOME AND ABROAD EVALUATED BY TOURISM OFFICIAL WEBSITE}

\section{A. Research Status at Home and Abroad}

Domestic research literature on the evaluation of tourism official website is relatively limited. The research perspective focuses on the marketing function and brand image building, function construction and overall evaluation, influence and performance evaluation, information and service evaluation, spatial distribution, etc. Gao Jing, etc (2007) selected information service, transaction processing, technical support, marketing strategy and website operation as a primary index to evaluate the marketing functions of 31 provincial government tourism websites in the marketing function aspect of tourism official website.[1] Li Junyi (2010) considered that the destination network marketing system should have the functions of information supply, information interaction, online transaction and relationship management, etc.[2] Wang Ya (2014) established four evaluation index system and 39 specific secondary indexes and analyzed the website of local cities in Shandong province.[3] Brand image is closely related to marketing function. Wu Xiangli, Hanning (2012) constructed the evaluation system of brand image building of government tourism website, determined the index weight by questionnaire survey and expert scoring and put forward the improvement suggestions.[4] Guo Jingjing and Hou Zhiqiang (2012) took Zhouzhuang tourism network as an example and drew specific content that local government spread tourism image through tourism official website.[5] The research on marketing publicity and brand image building originated from the theoretical research of tourism destination marketing. Tourism official website is an important platform for tourism destination marketing. No matter what level of administrative division, it should play the role. In this paper, the evaluation system of Hainan city and county tourism official website will also reflect the function of marketing and brand and reflect the reality of Hainan.

Government tourism official website construction belongs to public investment, so public management performance and influence should be generated. Some scholars have carried out the research on the overall evaluation and function construction of tourism website. Xu Huizhen (2012) evaluated the link characteristics and network influence of prefecture level Tourism Bureau official website in Guangdong province [6] by link analysis method. Jin Yigeng (2011) constructed Shaanxi tourism official website evaluation system [7] through 2 secondary indicators about decomposition, comprehensive cost management, online service efficiency, internal process, learning growth, partner efficiency, service level, 
administrative fees, and public value. The above evaluation was mostly based on provincial tourism official website and Lacked of tourism official website research of city and county level. Although Lian Hongyu (2007) has researched nearly 350 government travel websites, comparison of city and county level tourism official website is lack. This paper takes hainan as an example to carry out the survey of county-city level tourism website and regional comparison.

Li Li (2014) constructed index system and weight on the basis of expert investigation and analyzed the tourism administration network of 11 western provinces, cities and autonomous regions [8] on the basis of expert investigation by analytic hierarchy process for evaluation method of tourism official website. Liu Yapei (2013) determined and reviewed tourism official website of each local city in Jilin Province [9] based on analytic hierarchy process. This method is a mature method and suitable for tourism official website evaluation. This method is adopted in this paper.

\section{B. Foreign Research Status}

The research on the foreign tourism official website of the government is mostly related to the tourism destination marketing system. Mills (2006) have evaluated the marketing effect of tourism website by data statistics software [10] and this is similar to the domestic tourism official website marketing function evaluation; Morrison (2007) have obtained website multimedia technology, data such as performance and text, etc. which related to tourism destination marketing by data statistics software and researched the image of tourist destination [11] through expert scoring and other evaluation methods. Young A. Park and Ulrike Gretzel (2007) have proposed that 9 factors affecting the success of destination marketing websites are information quality, usability, responsiveness, security, visibility, trust, interactivity, personalization, transaction success rate. $\mathrm{Xu} \mathrm{Li}$ and You Cheng Wang (2011) have proposed that evaluating American tourism official website [12] from five dimensions which contain information, communication, transaction, customer relationship and technical value. There are also researches on the extension of tourism official website evaluation category, for example, Black(2000)have determined and reviewed four aspects which contain website planning, website management, website design, website content[13] obtaining data from the regional tourism department website of Australia by content analysis method. But the service object of tourism official website is not very concerned about website planning and website management. Evaluation of tourism official website should structure index system mostly from the use perspective of service object.

In summary, there are not so many direct researches on the tourism official website evaluation at city and county levels. The research on the official website evaluation of city and county government in Hainan is still blank and the application of analytic hierarchy process is relatively mature, so this paper takes it as the main research method. There are differences in the perspectives of existing studies. The main points of evaluation are hardware facilities of tourism official website, software service and content design, etc. Their focuses are on information services and functional applications and there is not much knowledge of hardware because of the function of government tourism official website is to be located in service tourists and tourism enterprises. Therefore, this paper will design the evaluation index system and collecting data because of the functional positioning of tourism official website and customer perspective and put forward the countermeasures to improve the city and county level tourism website construction in Hainan according to analysis.

\section{EVALUATION SYSTEM CONSTRUCTION OF GOVERNMENTAL TOURISM OFFICIAL WEBSITE AT CITY AND COUNTY LEVELS IN HAINAN}

The investigation will take 12 cities and counties including Haikou, Sanya, Qionghai, WenChang, Wuzhishan, Wanning, Chengmai, Qiongzhong, Baoting, Changjiang, Lingshui and Danzhou, etc which have opened tour official website and contained in 19 the counties and cities under the jurisdiction of Hainan.

For the construction of evaluation system, the purpose of governmental tourism website is to provide tourism public services, deal with tourism management affairs, promote the marketing of tourist destinations and promote the development of tourism destination, improve the informatization level of tourism industry. Government tourism official website evaluation is not limited to E-government, it also needs to cover e-commerce, information services and other fields. At the same time, government tourism official website evaluation should be based on the perception of the object as the main basis. Their participation and evaluations will intuitively reflect whether the tourism official website is effective to achieve the goal of construction. The participation of tourism enterprises is reflected in the application of tourism Egovernment. The use of tourism official website for tourists can be divided into different levels: First of all, tourist information services are required for tourist travelling. Website design directly influences visitors' judgment and choice of website. And online transactions are an extension of information services, and whether it is information services or online transactions, tourists always tend to interact. Online customer relationship management has become a new feature to win visitors' sustained attention for tourism official website in order to establish the brand perception to travel destination for visitors. The above evaluation dimension is also common for existing research. In addition, the technical support was brought into evaluation system by Wang Ya (2014), the website influence was used as evaluation index by Li Li (2014). But they are too professional or difficult to measure for visitors. Therefore, this paper evaluates the tourism official website of the cities and counties in Hainan by using analytic hierarchy process and selecting the six dimensions as secondary indicators which contain of e-government, information service, website design, online transaction, interactive communication and customer relationship management. The specific index system is as shown in "Table I". 
TABLE I. INDEX SYSTEM AND CORRESPONDING EVALUATION WEIGHT OF GOVERNMENTAL TOURISM OFFICIAL WEBSITE AT CITY AND COUNTY LEVELS IN HAINAN

\begin{tabular}{|c|c|c|c|c|c|}
\hline $\begin{array}{c}\text { Primary } \\
\text { Target } \\
\text { Layer }\end{array}$ & $\begin{array}{c}\text { Corres } \\
\text { pondin } \\
\mathbf{g} \\
\text { Weigh } \\
\mathbf{t}\end{array}$ & $\begin{array}{c}\text { Secondar } \\
\text { y } \\
\text { Criterion } \\
\text { Layer }\end{array}$ & $\begin{array}{c}\text { Corres } \\
\text { pondin } \\
\text { g } \\
\text { Weight }\end{array}$ & $\begin{array}{l}\text { Third-level } \\
\text { Index Layer }\end{array}$ & $\begin{array}{c}\text { Corres } \\
\text { pondin } \\
\text { g } \\
\text { Weight }\end{array}$ \\
\hline \multirow{19}{*}{$\begin{array}{l}\text { Informati } \\
\text { zation } \\
\text { of } \\
\text { tourism } \\
\text { official } \\
\text { website } \\
\text { at city } \\
\text { and county } \\
\text { levels }\end{array}$} & \multirow{19}{*}{$100 \%$} & \multirow{5}{*}{$\begin{array}{l}\text { B1 } \\
\text { Informatio } \\
n \text { service }\end{array}$} & \multirow{5}{*}{0.297} & $\begin{array}{l}\text { C1 Information } \\
\text { richness }\end{array}$ & 0.043 \\
\hline & & & & $\begin{array}{l}\text { C2 Dynamic } \\
\text { update of } \\
\text { information }\end{array}$ & 0.079 \\
\hline & & & & $\begin{array}{l}\text { C3 The } \\
\text { practicability of } \\
\text { information }\end{array}$ & 0.092 \\
\hline & & & & $\begin{array}{l}\text { C4 Diversity of } \\
\text { information } \\
\text { types }\end{array}$ & 0.048 \\
\hline & & & & $\begin{array}{l}\text { C5 Information } \\
\text { retrieval }\end{array}$ & 0.037 \\
\hline & & \multirow{3}{*}{$\begin{array}{l}\text { B2 } \\
\text { Website } \\
\text { design }\end{array}$} & \multirow{3}{*}{0.185} & $\begin{array}{l}\text { C6 Clear } \\
\text { website } \\
\text { navigation }\end{array}$ & 0.052 \\
\hline & & & & $\begin{array}{l}\text { C7 Website } \\
\text { running speed }\end{array}$ & 0.102 \\
\hline & & & & $\begin{array}{l}\text { C8 Website } \\
\text { layout effect }\end{array}$ & 0.031 \\
\hline & & \multirow{3}{*}{$\begin{array}{l}\text { B3 Online } \\
\text { trading }\end{array}$} & \multirow{3}{*}{0.131} & $\begin{array}{l}\text { C9 Convenient } \\
\text { network } \\
\text { transaction }\end{array}$ & 0.038 \\
\hline & & & & $\begin{array}{l}\text { C10 Website } \\
\text { security } \\
\text { guarantee }\end{array}$ & 0.079 \\
\hline & & & & $\begin{array}{l}\text { C11 Types of } \\
\text { trading } \\
\text { products }\end{array}$ & 0.015 \\
\hline & & \multirow{3}{*}{$\begin{array}{l}\text { B4 } \\
\text { Interactive } \\
\text { communic } \\
\text { ation }\end{array}$} & \multirow{3}{*}{0.156} & $\begin{array}{l}\text { C12 Website } \\
\text { online customer } \\
\text { service }\end{array}$ & 0.058 \\
\hline & & & & $\begin{array}{l}\text { C13 Visitor } \\
\text { interaction } \\
\text { platform }\end{array}$ & 0.066 \\
\hline & & & & $\begin{array}{lr}\text { C14 } & \text { Other } \\
\text { social } & \text { platform } \\
\text { links } & \\
\end{array}$ & 0.032 \\
\hline & & \multirow{3}{*}{$\begin{array}{l}\text { B5 } \\
\text { Customer } \\
\text { relationshi } \\
\text { p } \\
\text { manageme } \\
\text { nt }\end{array}$} & \multirow{3}{*}{0.150} & $\begin{array}{l}\text { C15 Online } \\
\text { complaint } \\
\text { handling }\end{array}$ & 0.052 \\
\hline & & & & $\begin{array}{l}\text { C16 } \\
\text { Promotional } \\
\text { activities } \\
\end{array}$ & 0.043 \\
\hline & & & & $\begin{array}{l}\text { C17 Opinion } \\
\text { feedback survey }\end{array}$ & 0.054 \\
\hline & & \multirow{2}{*}{$\begin{array}{l}\text { B6 E- } \\
\text { governme } \\
\text { nt }\end{array}$} & \multirow{2}{*}{0.081} & $\begin{array}{l}\text { C18 } \\
\text { Government } \\
\text { affairs are Open } \\
\text { and transparent }\end{array}$ & 0.059 \\
\hline & & & & $\begin{array}{l}\text { C19 } \\
\text { Convenient } \\
\text { online office }\end{array}$ & 0.022 \\
\hline
\end{tabular}

IV. MEASUREMENT SCORE OF GOVERNMENTAL TOURISM OFFICIAL WEBSITE AT CITY AND COUNTY LEVELS IN HAINAN

\section{A. Evaluation Weight Index Based on Analytic Hierarchy}

Analytic hierarchy process is called AHP method for short and proposed by American operations scientists T.L.Saaty [14] in the early 1970s. 20 experts of tourism informatization are selected to determine the matrix of judgment matrix and make group decision calculation after several feedbacks and revise for determining index weight. The mode to judge matrix is aggregated by geometric mean. To adjust judgment matrix by minimum change method for the phenomenon of inconsistent judgment matrix, finalize the consistency coefficient of each judgment matrix is less than 0.1 and meet the requirements of analytic hierarchy process. The expert weight rating scale is calculated by Yaahp10 software, and then we can obtain the weight of each level. The corresponding weight of each index is shown in "Table I".

\section{B. Data Analysis Based on Fuzzy Evaluation}

The evaluation adopts the method of fuzzy evaluation and 1-5 points express very bad, not good, general, good, and very good respectively. A total of 250 questionnaires were distributed and Yaahp10 software was used to calculate the comprehensive score and itemized score of the informatization evaluation of tourism official website of various cities and counties. For details, see Table 2. The overall mean of cities and counties is 3.257 and Only Sanya, Haikou, Baoting and Lingshui exceed the mean value.

1) There are differences among different regions: There are Haikou and Chengmai in the north, Danzhou and Changjiang in the west, Sanya and Baoting in the south, Wuzhishan and Qiongzhong in the middle, WenChang, Qionghai, Lingshui and Wanning in the east which contained in 12 cities and counties. The mean is: 3.336 in the north, 3.085 in the west, 3.703 in the south, 3.080 in the middle and 3.170 in the east. Cities and counties in southern Hainan scored higher, the northern is second; Eastern is lower; the weakest is western and central and they are also the areas where tourism development in Hainan started relatively late.

2) Index score: Combine the mean value and weight of each third-level index and then get the actual score. After accumulation, the city and county comprehensive score will be obtained. The mean value of the actual score of the 19 third-level indexes was 0.171 and which much less than the mean are C5 Information retrieval (0.130), C8 Website layout effect (0.102), C9 Convenient network transaction (0.069), C11 Types of trading products (0.047), C14 Other social platform links (0.105), C16 Promotional activities (0.140), C19 Convenient online office (0.069); Which little less than the mean are C1 Information richness (0.158), C4 Diversity of information types (0.169), C15 Online complaint handling (0.161), C17 Opinion feedback survey (0.153); Which little higher than the mean are C6 Clear website navigation (0.188), C10 Website security guarantee (0.195), C12 Website online customer service (0.197); Which more higher than the mean are C2 Dynamic update of information (0.282), C7 Website running speed (0.348), C13 Visitor interaction platform (0.203), C18 Openness and transparency of government affairs (0.200). The informatization problem of government tourism official website are reflected in the function is weaker, 
the effect of layout design needs to be improved, information is not easy to use and online office is lagged.

3) Secondary index score: Obtain the average of secondary index according to table 3 and index weight. The mean of information service, website design, online trading, interactive communication, customer relationship management, e-government and other secondary indicators are: $1.053,0.638,0.338,0.505,0.454$, and 0.269 . Their combined mean is 0.543 . "Information service" and "website design" are higher than the mean value; "Interactive communication" is slightly lower than this and "Egovernment", "online transaction" and "customer relationship management" are significantly lower than the mean as shonw in "Table II".

TABLE II. ThE SCORE AND TOTAL SCORE AFTER THE EVALUATION INDEX WEIGHTING OF THE TOURISM OFFICIAL WEBSITE OF 12 GOVERNMENTS AT City AND COUNTY LEVELS IN HAINAN

\begin{tabular}{|c|c|c|c|c|c|c|c|c|c|c|c|c|c|}
\hline $\begin{array}{c}\text { Cities and } \\
\text { counties } \\
\text { Third-level index }\end{array}$ & Sanya & $\begin{array}{c}\text { Haiko } \\
\text { u }\end{array}$ & $\begin{array}{c}\text { Baotin } \\
\mathrm{g}\end{array}$ & $\begin{array}{l}\text { Lingsh } \\
\text { ui }\end{array}$ & $\begin{array}{l}\text { WenC } \\
\text { hang }\end{array}$ & $\begin{array}{c}\text { Wanni } \\
\text { ng }\end{array}$ & $\begin{array}{l}\text { Qiongz } \\
\text { hong }\end{array}$ & $\begin{array}{c}\text { Danzh } \\
\text { ou }\end{array}$ & $\begin{array}{l}\text { Chang } \\
\text { jiang }\end{array}$ & $\begin{array}{l}\text { Cheng } \\
\text { mai }\end{array}$ & $\begin{array}{l}\text { Wuzhi } \\
\text { shan }\end{array}$ & $\begin{array}{l}\text { Qiong } \\
\text { hai }\end{array}$ & $\overline{C_{i} W_{i}}$ \\
\hline $\begin{array}{l}\mathrm{C} 1 \text { Information } \\
\text { richness }\end{array}$ & 0.183 & 0.177 & 0.172 & 0.164 & 0.155 & 0.155 & 0.152 & 0.151 & 0.147 & 0.147 & 0.151 & 0.143 & 0.158 \\
\hline $\begin{array}{l}\text { C2 Dynamic update } \\
\text { of information }\end{array}$ & 0.338 & 0.350 & 0.312 & 0.299 & 0.252 & 0.287 & 0.283 & 0.262 & 0.285 & 0.250 & 0.258 & 0.208 & 0.282 \\
\hline $\begin{array}{lr}\text { C3 } & \text { The } \\
\text { practicability } & \text { of } \\
\text { information } & \\
\end{array}$ & 0.355 & 0.353 & 0.345 & 0.319 & 0.304 & 0.319 & 0.301 & 0.301 & 0.295 & 0.293 & 0.295 & 0.283 & 0.313 \\
\hline $\begin{array}{l}\text { C4 Diversity of } \\
\text { information types }\end{array}$ & 0.195 & 0.193 & 0.179 & 0.174 & 0.160 & 0.164 & 0.169 & 0.161 & 0.157 & 0.162 & 0.164 & 0.153 & 0.169 \\
\hline $\begin{array}{l}\text { C5 Information } \\
\text { retrieval }\end{array}$ & 0.149 & 0.122 & 0.136 & 0.133 & 0.139 & 0.133 & 0.127 & 0.128 & 0.130 & 0.119 & 0.128 & 0.122 & 0.130 \\
\hline $\begin{array}{l}\text { C6 Clear website } \\
\text { navigation }\end{array}$ & 0.211 & 0.205 & 0.202 & 0.190 & 0.185 & 0.185 & 0.185 & 0.185 & 0.174 & 0.187 & 0.171 & 0.170 & 0.188 \\
\hline $\begin{array}{l}\text { C7 Website running } \\
\text { speed }\end{array}$ & 0.371 & 0.420 & 0.391 & 0.366 & 0.344 & 0.365 & 0.370 & 0.362 & 0.340 & 0.349 & 0.234 & 0.263 & 0.348 \\
\hline $\begin{array}{l}\text { C8 Website layout } \\
\text { effect }\end{array}$ & 0.124 & 0.104 & 0.121 & 0.109 & 0.102 & 0.099 & 0.101 & 0.097 & 0.092 & 0.088 & 0.098 & 0.091 & 0.102 \\
\hline $\begin{array}{l}\text { C9 Convenient } \\
\text { network transaction }\end{array}$ & 0.138 & 0.096 & 0.103 & 0.115 & 0.090 & 0.098 & 0.091 & 0.083 & 0.092 & 0.079 & 0.085 & 0.094 & 0.097 \\
\hline $\begin{array}{l}\text { C10 } \\
\text { security } \\
\text { guarantee }\end{array}$ & 0.275 & 0.203 & 0.205 & 0.223 & 0.173 & 0.204 & 0.181 & 0.171 & 0.181 & 0.162 & 0.176 & 0.182 & 0.195 \\
\hline $\begin{array}{l}\text { C11 Types of } \\
\text { trading products }\end{array}$ & 0.060 & 0.052 & 0.049 & 0.050 & 0.044 & 0.046 & 0.045 & 0.041 & 0.045 & 0.043 & 0.042 & 0.043 & 0.047 \\
\hline $\begin{array}{l}\text { C12Online customer } \\
\text { service of website }\end{array}$ & 0.244 & 0.232 & 0.206 & 0.197 & 0.189 & 0.191 & 0.205 & 0.173 & 0.182 & 0.189 & 0.165 & 0.187 & 0.197 \\
\hline $\begin{array}{ll}\text { C13 } & \text { Visitor } \\
\text { interaction platform }\end{array}$ & 0.246 & 0.213 & 0.220 & 0.225 & 0.191 & 0.203 & 0.204 & 0.197 & 0.217 & 0.167 & 0.196 & 0.161 & 0.203 \\
\hline $\begin{array}{l}\text { C14 other social } \\
\text { platforms Links }\end{array}$ & 0.123 & 0.091 & 0.117 & 0.113 & 0.117 & 0.101 & 0.102 & 0.106 & 0.100 & 0.100 & 0.108 & 0.081 & 0.105 \\
\hline $\begin{array}{l}\text { C15 Online } \\
\text { complaint handling }\end{array}$ & 0.203 & 0.168 & 0.166 & 0.165 & 0.153 & 0.161 & 0.163 & 0.144 & 0.141 & 0.166 & 0.154 & 0.147 & 0.161 \\
\hline $\begin{array}{l}\text { C16 Promotional } \\
\text { activities }\end{array}$ & 0.175 & 0.157 & 0.154 & 0.143 & 0.140 & 0.134 & 0.137 & 0.131 & 0.132 & 0.129 & 0.123 & 0.127 & 0.140 \\
\hline $\begin{array}{l}\text { C17 Opinion } \\
\text { feedback survey }\end{array}$ & 0.200 & 0.174 & 0.145 & 0.159 & 0.172 & 0.150 & 0.141 & 0.146 & 0.131 & 0.144 & 0.142 & 0.133 & 0.153 \\
\hline $\begin{array}{l}\text { C18 Openness and } \\
\text { transparency of } \\
\text { government affairs }\end{array}$ & 0.241 & 0.236 & 0.206 & 0.205 & 0.224 & 0.155 & 0.171 & 0.206 & 0.159 & 0.201 & 0.211 & 0.186 & 0.200 \\
\hline $\begin{array}{l}\text { C19 Convenient } \\
\text { online office }\end{array}$ & 0.085 & 0.084 & 0.063 & 0.072 & 0.077 & 0.058 & 0.059 & 0.073 & 0.053 & 0.068 & 0.074 & 0.063 & 0.069 \\
\hline$\sum_{1}^{19} C_{i} W_{i}$ & 3.914 & 3.629 & 3.492 & 3.419 & 3.212 & 3.209 & 3.187 & 3.118 & 3.052 & 3.042 & 2.973 & 2.839 & 3.257 \\
\hline
\end{tabular}

Notes: In table 2, Ci represents the absolute mean of Ci evaluation of the evaluation index of single city counties (not weight). Wi represents the weight corresponding to the index Ci. CiWi represents the mean of the weighted score of the 12 cities and counties in the evaluation index $\mathrm{Ci}$.

V. THE IDEA OF OPTIMIZING AND UPGRADING ABOUT GOVERNMENTAL TOURISM OFFICIAL WEBSITES AT CITY AND COUNTY LEVELS IN HAINAN

First, narrow the gap of tourism official websites construction effect at city and county levels. In addition to Sanya, Haikou, Baoting, Lingshui, informatization level about the tourism official website of other cities and counties in
Hainan is low or no official website. This is limited to the late development of local tourism resources and the development of tourism economy and lack of necessary project driving and funding. The construction of tourism official website plays an active role in attracting tourists and attracting tourists. And the tourism industry transformation and upgrading and the development of intelligent tourism need to attract sufficient 
attention to the construction of government tourism official website. Give special input, carry out experience exchange and

Second, improve the service function of the online office of tourism administration. Hainan tourism government office function focuses on the official website of the provincial tourism commission and the online office functions of tourism administration in cities and counties are limited. On the one hand, the local tourism board lacks the corresponding approval authority. In addition, the number of businesses contacted by the local tourism bureau is small. With the decentralization of administrative examination and approval power in the future, the management functions of local tourism administration departments will be strengthened. And the tourism government online office and business processing are the main objectives of e-government. The online office function of tourism government should be expanded and improved service quality.

Third, improve the information and channels of online travel transactions. Tourism online trading is not the main function of government tourism official website. However, the tourists in the information age are faced with complicated and complicated information, which urgently needs public information service to complete online travel transactions conveniently and efficiently. Because of the limitations of communication and coordination with personnel, financial resources and merchants, the types of tourism business information provided by the tourism management department are not complete enough, the update is lagging behind, and it can not meet the needs of tourists. We should give full play to the function of public management in the future, select and recommend trustworthy brand merchants and open up convenient trading channels and ensuring safety.

Finally, optimize site layout design and highlight interactive features. Layout design is the key to attract visitors to in-depth browsing and use. Most tourism official websites layout design of cities and counties is too simple in Hainan, the visual effect is so bad and there are too many information and lack of internal retrieval. In addition, the participation and interactive communication platform is lack and advisory telephone provided is no answer in the process of customers browsing the website or consumption process. It is suggested to use modern information technology and means and enrich the communication platform with customers, for example, WeChat public number, App software and so on to achieve deep docking with customers and effectively enhance the government tourism official website information level.

\section{CONCLUSION}

The service function of each travel website should be further optimized Based on the research of the hierarchical analysis in which there are significant regional differences in the construction of tourism official websites in various cities and counties of Hainan. Meet the overall needs of the use of objects; narrow the gap between regions and enhance the overall level of tourism informatization in Hainan through perfecting the public information service and online transaction function of tourism.

\section{REFERENCES}

[1] Gao Jing, Qi Tianfeng, Zhang Yonggang. Empirical analysis of local government official tourism website marketing function[J]. Geography and Geographic Information Science, 2007,23(2):104-108.

[2] Li Junyi. Evaluation of tourism destination network marketing system based on tourists' needs - Take China's provincial tourism website as an example[J]. Tourism Tribune, 2010,25(8):45-51.

[3] Wang Ya. Research on the evaluation of tourism destination website marketing function - Take the tourism website of 17 cities in Shandong as an example[D]. Jinan: Shandong University, 2014:28-31.

[4] Wu Xiangli, Haining. Evaluation of destination brand image building based on local government tourism portal website - Taking 33 provinces, cities and districts as the example of official portal information website in China [J]. Travel Forum, 2012,5(1):93-96.

[5] Guo Jingjing, Hou Zhiqiang. Research on the construction of government tourism websites and tourism destination image - Taking Zhouzhuang tourism network as an example, [J]. Journal of Leshan Teachers College, 2012,28(27):73-76.

[6] $\mathrm{Xu}$ Huizhen. Research on the influence of official tourism websites in destination - From the point of view of link analysis [J]. Modern intelligence, ,2012,32(10):93-96.

[7] Jin Yigeng. Research on fuzzy comprehensive evaluation of tourism Egovernment Performance — Take the official website of Shaanxi Tourism Bureau as an example, [D]. Xi'an: Shaanxi Normal University, 2011:22-24.

[8] Li Li. Evaluation of tourism government website based on analytic hierarchy process $[\mathrm{J}]$. Journal of Chongqing second normal college, ,2014,27 (6):44-48.

[9] Liu Yafei. Research on the evaluation index system of tourism official website based on AHP - Take nine prefecture level cities in Jilin Province as an example, [D]. Changchun: Northeast Normal University, 2013:16-20.

[10] Han,J.H. \& Mills, J. E(2006). Zero acquaintance benchmarking at travel destination websites: what is the first impression that national tourism organizations try to make?[J].International Journal of Tourism Research,8(6):405-430.

[11] Choi,S., Lehto, X. Y. \& Morrison,A.M(2007). Destination image representation on the web: content analysis of Macau travel related website[J].Tourism Management,28(1):118-129.

[12] Xu Li and You cheng Wang(2011). Measuring the effectiveness of US official state tourism websites[J].Journal of Vacation Marketing,17(4):287-302.

[13] Benckendorff, P.J., \& Black, N.L(2000). Destination marketing on the internet: a case study of Australian regional tourism authorities[J].Journal of Tourism Studies, 11(1):11-21.

[14] Xu Shubo. Principles of analytic hierarchy process[M]. Tianjin: Tianjin University press, 1988:82-88. 